\title{
COMPOSITION OF TESTICULAR AND EPIDIDYMAL LYMPH IN THE RAM
}

\author{
J. C. WALLACE AND A. K. LASGELLES \\ Department of Veterinary Physiology, University of Sydney, \\ Sydney, N.S.W., and \\ Dairy Husbandry Research Foundation, University of Sydney, \\ University Farms, Camden, N.S.W., Australia
}

(Received 27th February 1964)

\begin{abstract}
Summary. An analysis of jugular blood plasma and testicular lymph collected from conscious rams has been carried out. The white cell content of the testicular lymph was 100 to 400 cells/ $\mu l$ and most of the cells were medium lymphocytes. In general the chemical composition of the testicular lymph was similar to that of the lymph collected from other regions of the body of sheep and other animals. The unusual composition of testicular and epididymal fluids thus was not reflected in the composition of the lymph. There was a large plasma-lymph gradient for lactate and glucose suggesting that these substances are utilized by testicular tissue. The free fatty acid level in lymph was somewhat lower than in plasma.
\end{abstract}

\section{INTRODUCTION}

The volume and composition of tissue fluid formed in an organ are to a large extent determined by the exchange of solutes and water through the capillary walls (Yoffey \& Courtice, 1956). However, in the testis and epididymis, which are organs with specialized metabolic activities, the testicular and epididymal fluids differ in their composition from that of plasma, as shown by Scott, Wales, Wallace \& White (1963) in the ram.

It is not possible to collect tissue fluid directly for biochemical analysis but as regional lymph is believed to be derived directly from the tissue fluid, changes which have occurred in the formation of the tissue fluid will ultimately be reflected in the flow and composition of the lymph. Using a technique which permits the collection of lymph from the testis and epididymis of rams for long periods of time under essentially physiological conditions (Cowie, Lascelles \& Wallace, 1964), it has been possible to carry out extensive biochemical analyses of this lymph (and of plasma from the jugular vein) to learn more about the internal environment of these organs with a view to relating these findings to some of their unique biochemical properties and functions. 


\section{Experimental animals}

\section{MATERIALS AND METHODS}

One Dorset Horn and five Merino rams of mature age were used.

\section{Operative technique}

The anaesthetic and surgical techniques described by Cowie et al. (1964) were adopted. The main lymphatic ducts draining the testis and epididymis were dissected free of the spermatic vein at the level of the external inguinal ring. The ducts were ligated and one to three of the larger ducts were cannulated with Transflex (Minnesota Mining \& Manufacturing Co, New York) tubing (internal diameter 1.2 to $1.5 \mathrm{~mm}$ ). After the operations the rams were confined in small pens and fed a ration of crushed oats and lucerne hay.

\section{Blood and lymph sampling}

Collection of plasma and lymph samples for analysis was commenced 36 to $48 \mathrm{hr}$ after the operation when the animals were clinically normal and the lymph flowed at maximum and constant rates of approximately $10 \mathrm{ml} / \mathrm{hr}$. Jugular blood and testicular lymph samples were collected simultaneously into tubes containing heparin ('Pularin', Evans Medical Supplies). The cells were removed by centrifugation and the supernatant plasma or lymph were stored at $4^{\circ} \mathrm{C}$ or $-20^{\circ} \mathrm{C}$.

Blood and lymph samples intended for bicarbonate analysis were collected under paraffin into tubes containing sodium fluoride and heparin, following the recommendations of Peters \& Van Slyke (1956). Cells were separated from the plasma and lymph by centrifugation after the tubes had been filled with paraffin and tightly stoppered with serum caps.

\section{Analytical techniques}

These were as follows. Total protein and albumen (Gornall, Bardawill \& David, 1949); total esterified fatty acids (Stern \& Shapiro, 1953); phospholipids (Zilversmit \& Davis, 1950); cholesterol (Rappaport \& Eickhorn, 1960); glucose (Huggett \& Nixon, 1957) (glucose oxidase); free fatty acids (Dole, 1956); orcinol-reactive carbohydrate (Hewitt, 1937) (after separating the acidsoluble and acid-insoluble fractions by the addition of two volumes of $20 \%$ w/v tricholoroacetic acid); lactic acid (Barker \& Britton, 1957) (lactic dehydrogenase); citric acid (Lindner \& Mann, 1960); glycerylphosphorylcholine (GPC) (White, 1959); sodium, potassium, calcium and magnesium were estimated with an atomic absorption spectrophotometer (B. G. Davey, personal communication, 1961); inorganic phosphate (Zilversmit \& Davis 1950); bicarbonate was determined by adding excess hydrochloric acid to the plasma or lymph to liberate all the carbon dioxide, and titrating the sample back with $0.01 \mathrm{~N}-\mathrm{NaOH}$ to $\mathrm{pH} 7 \cdot 4$, using phenol red as the indicator and a paraffin-sealed plasma or lymph specimen of $\mathrm{pH} 7.4$ as a standard for the end point (Van Slyke, 1922); and chloride (Santavy, 1948), polarographically or titrimetrically by Sendroy's (1937) silver iodate method as described by Peters \& Van Slyke (1956). 
Testicular lymph in rams

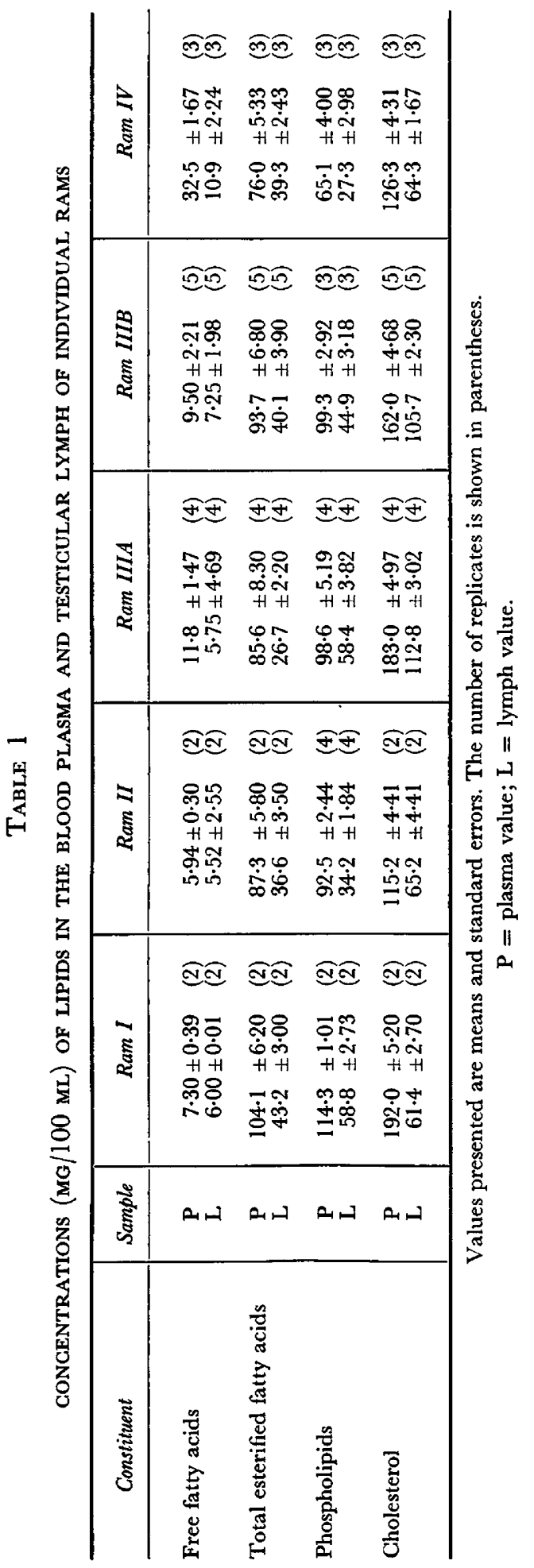


White cell counts

White cells were counted in a haemocytometer. Stained films were prepared by centrifuging lymph at $1000 \mathrm{rev} / \mathrm{min}$ for $5 \mathrm{~min}$ and re-suspending the cells in a small volume of $10 \%$ crystalline bovine albumen solution (Armour, England). Thick films were prepared, air dried and stained with Leishman's stain.

\section{Proteins and lipids}

\section{RESULTS}

The values for protein content of plasma and of testicular lymph of four of the six rams used in the present investigation have been reported elsewhere (Cowie et al., 1964). The protein content of the lymph was very high, varying between 59 and $72 \%$ of plasma values. The values for esterified fatty acids, cholesterol and phospholipids are presented in Table 1, from which it can be seen that the values for lymph were considerably lower than those for plasma. In general the relative concentration of these components in plasma and lymph follows the distribution of the globulins. The free fatty acid levels were higher in plasma than in corresponding lymph samples and the magnitude of the difference was significantly correlated with the plasma level $(r=0.99$; d.f. $=3 ; P<0.001)$.

\section{Carbohydrate, glycerylphosphorylcholine, lactic acid and citric acid}

The results are presented in Table 2. The plasma levels of glucose were significantly higher (18 to $54 \%$ ) than the corresponding levels in lymph $(P<0 \cdot 01)$, glucose accounting for the bulk of reducing sugar in both plasma and lymph and also for most of the acid-soluble orcinol-reactive carbohydrate. The lactate levels in plasma were 51 to $137 \%$ higher than in lymph. The concentration of acid-insoluble orcinol-reactive carbohydrate (representing the carbohydrate moiety of the mucoproteins) was higher in plasma than in lymph; this difference was paralleled by differences in the globulin levels. The GPC and citrate levels in both plasma and lymph were low and varied considerably. There was no consistent gradient between the plasma and lymph.

\section{Electrolytes}

The results are presented in Table 3. There were no significant differences between the concentrations of sodium, potassium and inorganic phosphate in plasma as against lymph, but the calcium and magnesium concentrations were significantly higher and chloride significantly lower in the plasma $(P<0.001$; $P<0.01$ and $P<0.05$ respectively). In the two rams in which bicarbonate determinations were carried out concentrations in the lymph were significantly higher than in the corresponding plasma samples $(P<0.01)$. The relation between the acid and alkaline equivalents in the blood plasma and lymph, respectively, is set out according to the method of Gamble (1954) in Text-fig. 1. It demonstrates the closeness of acid-base equivalence in the plasma and testicular lymph. 


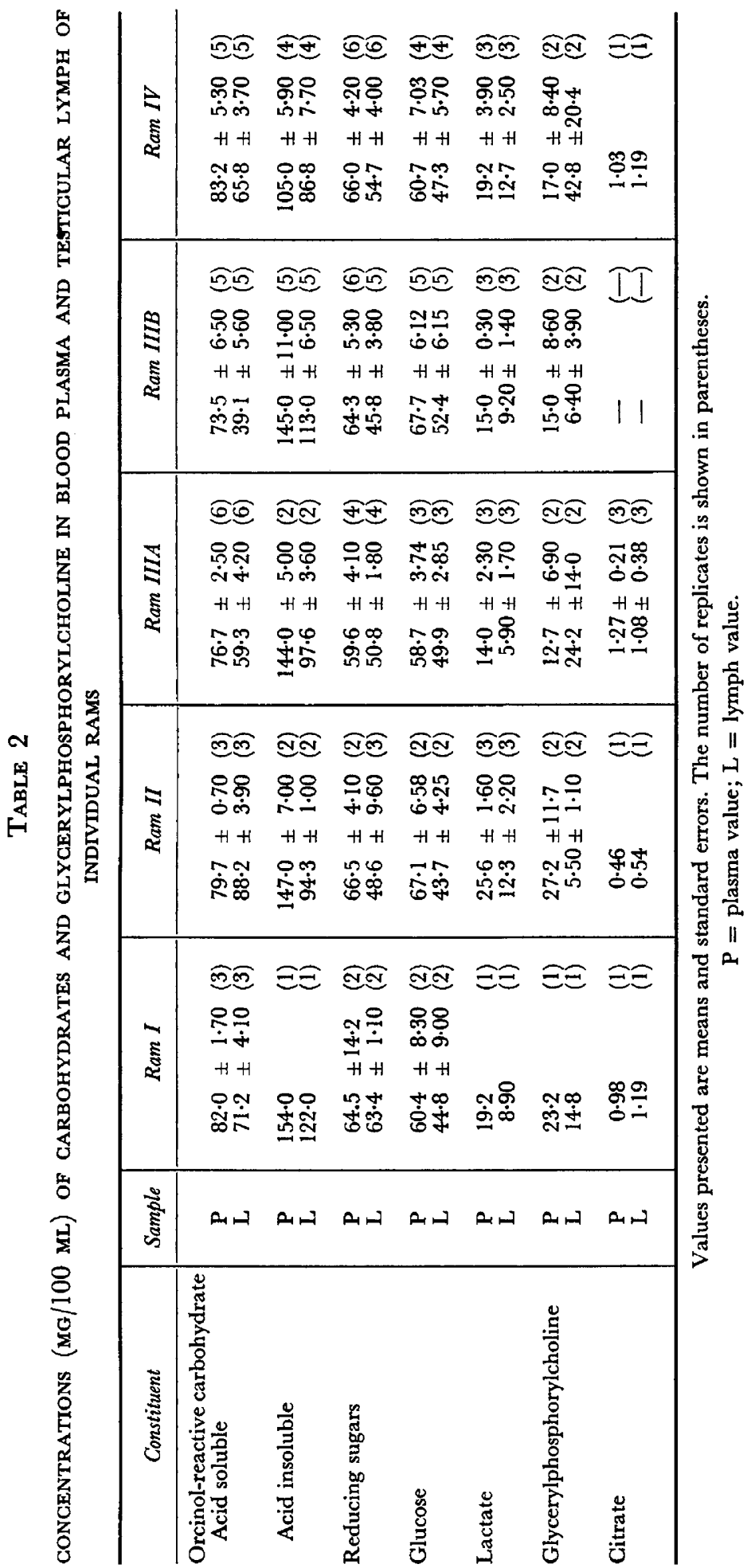




\section{Cell content}

Except for a very short period after operation there were no red cells present in the testicular lymph. The white cell content in the lymph of the various rams

TABLE 3

CONCENTRATIONS (M-EQUIV/L) OF THE MAJOR ELECTROLYTES IN THE BLOOD PLASMA AND TESTICULAR LYMPH OF RAMS

\begin{tabular}{|c|c|c|}
\hline & Plasma & Lymph \\
\hline $\begin{array}{l}\text { Sodium } \\
\text { Potassium } \\
\text { Calcium } \\
\text { Magnesium } \\
\text { Inorganic phosphate } \\
\text { Bicarbonate } \\
\text { Chloride }\end{array}$ & $\begin{array}{r}144.3 \pm 1.50(11) \\
3.80 \pm 0.14 \quad(11) \\
4.76 \pm 0.17(11) \\
1.69 \pm 0.06 \quad(11) \\
2.99 \pm 0.26(17) \\
26.2 \pm 0.42 \\
107.8 \pm 1.10\end{array}$ & $\begin{array}{r}144 \cdot 4 \pm 1 \cdot 90(11) \\
3.79 \pm 0 \cdot 10(11) \\
4.33 \pm 0.37(11) \\
1.50 \pm 0.04(11) \\
3 \cdot 19 \pm 0.26(17) \\
28 \cdot 6 \pm 0.70(6) \\
111.3 \pm 1.80(12)\end{array}$ \\
\hline
\end{tabular}

Values presented are means and standard errors computed for each constituent over all rams. The number of replicates is shown in parentheses.

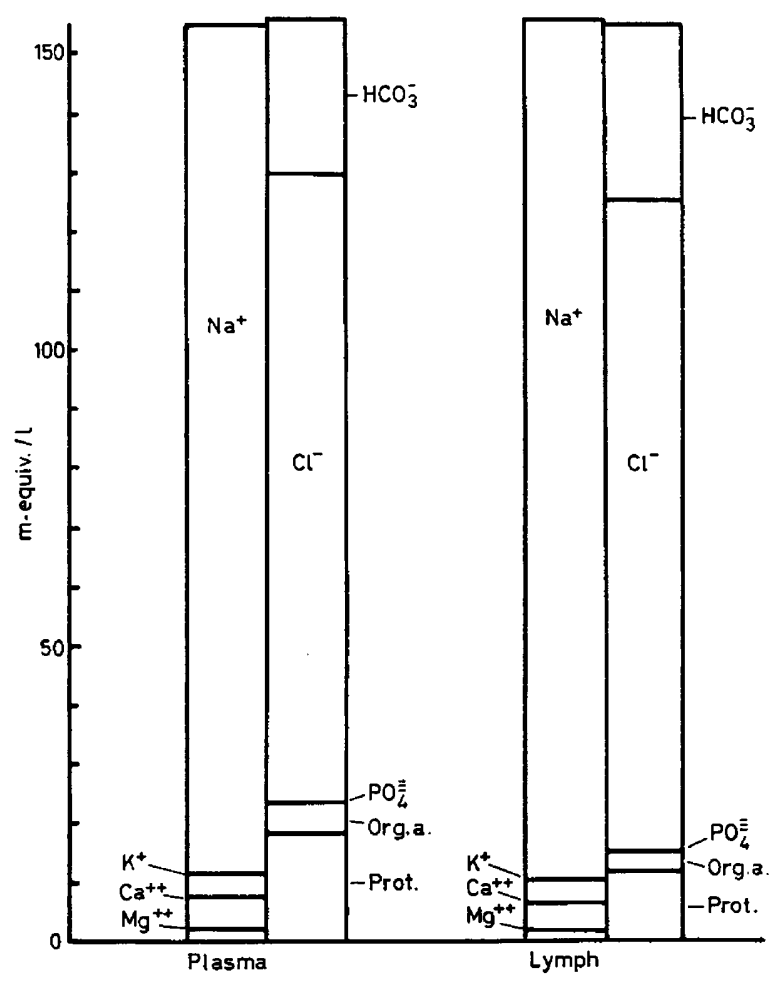

TexT-FIG. 1. Relation between the acid and alkaline equivalents in the blood plasma and testicular lymph of rams.

ranged between 100 and 400 cells $/ \mu$, and at least $95 \%$ of the cells were lymphocytes. A large proportion of these were medium lymphocytes, but occasionally macrophages and polymorphs were seen. The very low cell content of the lymph is not surprising since the lymphatics were cannulated on the afferent side of the regional lymph nodes. 


\section{DISCUSSION}

The lower concentrations of glucose and lactate in lymph than in jugular plasma suggest an uptake of these substances by testicular and epididymal tissue. Uptake and oxidation of glucose by the testis and epididymis of anaesthetized rams has been previously demonstrated using arterio-venous difference and isotope dilution techniques with ${ }^{14} \mathrm{C}$-labelled substrates (Annison, Scott \& Waites, 1963). Similar data for lactate are, however, not available at present.

Since reducing sugars are absent from the testicular and epididymal fluids (Mann, 1946; White \& Wales, 1961) and the chief source of the high concentration of seminal fructose is the seminal vesicle (Mann, 1946; Davies \& Mann, 1947 ), it is not surprising that it is glucose which accounts for virtually all the reducing sugar acid-soluble carbohydrate in the testicular and epididymal lymph.

The concentration of free fatty acid in lymph is also somewhat lower than in the plasma, and this again may be a reflection of the uptake of these substances by testicular and epididymal tissue. This finding recalls the observation by Lascelles \& Morris (1961) who found a higher free fatty acid concentration in plasma than in the mammary lymph of lactating sheep. In general, total esterified fatty acids, cholesterol and phospholipids in plasma and lymph followed the distribution of the globulins, possibly because these lipids occur in a protein-bound form. This finding conforms with the published data on the concentrations of these substances in plasma and lymph collected from other regions of the body (Yoffey \& Courtice, 1956). There is no suggestion, however, that the difference in the concentration of these components in plasma and lymph is a reflection of their uptake by the testicular and epididymal tissue.

Despite the very high concentrations of GPC in the epididymal fluid of the ram, there was no evidence of its transfer into the tissue fluid in an appreciabie quantity. Conversely there was no indication of its uptake from the blood, which is not surprising since in the rat, rabbit and guinea-pig the epididymis is capable of synthesizing GPC (Dawson \& Rowlands, 1959; Scott, Dawson \& Rowlands, 1963; Scott, Wales, Wallace \& White, 1963).

The concentrations of the electrolytes in testicular lymph are similar to those in lymph collected from other regions of the body (Yoffey \& Courtice, 1956). The markedly different concentrations of sodium and potassium in testicular and epididymal fluids relative to those in blood plasma (Scott, Wales, Wallace \& White, 1963) have not been reflected in the testicular lymph. The unusual electrolyte environment of milk was also not found to influence the composition of mammary lymph (Linzell, 1960; Lascelles \& Morris, 1961; Reynolds, 1962). The concentration of bicarbonate and chloride in testicular lymph was higher than that of corresponding plasma samples, and in terms of anionic equivalence the higher levels of bicarbonate and chloride in the lymph more or less compensate for the lower levels of organic acid and protein in the lymph.

\section{ACKNOWLEDGMENTS}

The authors are indebted to Professors C. W. Emmens and T. J. Robinson for their encouragement and advice. We are grateful to Miss J. Rock for technical 
assistance, and to Dr B. G. Davey and Mr J. Robinson of the School of Agriculture for their help with the atomic absorption analyses.

The work was aided by grants from the Lalor Foundation and the Rural Credits Development Fund of the Commonwealth Bank of Australia. One of us (J. C. W.) was supported by a Commonwealth Post-Graduate Studentship.

\section{REFERENCES}

Annison, E. F., Scotr, T. W. \& Wartes, G. M. H. (1963) The role of glucose and acetate in the oxidative metabolism of the testis and epididymis of the ram. Biochem. 7. 88, 482 .

Barker, J. N. \& Britton, H. G. (1957) The enzymatic estimation of L(+) lactic acid. J. Physiol. 138, 3P.

Cowie, A. T., Lascelles, A. K. \& Wallace, J. G. (1964) The flow and protein content of testicular lymph in conscious rams. 7. Physiol. 171, 176.

Davies, D. V. \& MANN, T. (1947) Functional development of accessory glands and spermatogenesis. Nature, Lond. 160, 295.

Dawson, R. M. C. \& Rowlands, I. W. (1959) Glycerylphosphorylcholine in the male reproductive organs of rats and guinea pigs. Quart. 7. exp. Physiol. 44, 26.

Dole, V. P. (1956) A relation between non-esterified fatty acids in plasma and the metabolism of glucose. 7. clin. Invest. 35, 156.

Gamble, J. L. (1954) Chemical anatomy, physiology and pathology of extracellular fluid. Harvard University Press, Cambridge, Mass.

Gornall, A. G., Bardawill, C. J. \& David, M. N. (1949) Determination of serum proteins by means of the biuret reaction. 7. biol. Chem. 177, 751 .

Hewit, L. F. (1937) Separation of serum albumin into two fractions. 2. Observations on the nature of the glycoprotein fraction. Biochem. 7. 31, 360 .

Huggetr, A. St. G. \& Nixon, D. A. (1957) Enzymic determination of blood glucose. Biochem. 7. 66, $12 \mathrm{P}$.

Lascelles, A. K. \& Morris, B. (1961) The flow and composition of lymph from the mammary gland in merino sheep. Quart. F. exp. Physiol. 46, 206.

Lindner, H. R. \& MANn, T. (1960) Relationship between the content of androgenic steroids in the testis and the secretory activity of the seminal vesicles in the bull. 7 . Endocrin. 21, 341 .

Linzell, J. L. (1960) The flow and composition of mammary gland lymph. 7. Physiol. 153, 510.

ManN, T. (1946) Studies on the metabolism of semen. 3. Fructose as a normal constituent of seminal plasma. Site of formation and function of fructose in semen. Biochem. $7.40,481$.

Peters, J. P. \& VAN Slyke, D. D. (1956) Quantitive clinical chemistry, vol. 2. Williams \& Wilkins, Baltimore.

RAPPAPORT, F. \& Eickhorn, F. (1960) Sulphosalicylic acid as a substitute for $p$-toluene sulphonic acid. A. In the estimation of cholesterol. Clin. chim. Acta, 5, 161.

Reynolds, M. (1962) Composition of mammary lymph in lactating goats. 7. Dairy Sci. 45, 742.

Santavy, F. (1948) In Polarography in medicine, biochemistry and pharmacy, p. 124. Ed. M. Brezina and P. Zuman. Interscience, New York.

Scotr, T. W., Dawson, R. M. G. \& Rowlands, I. W. (1963) Phospholipid interrelationship in rat epididymal tissue and spermatozoa. Biochem. $\mathbf{7} .87,507$.

Scott, T. W., Wales, R. G., Wallace, J. G. \& White, I. G. (1963) Composition of ram epididymal and testicular fluid and the biosynthesis of glycerylphosphorylcholine by the rabbit epididymis. 7. Reprod. Fertil. 6, 49.

SENDRoy, J. (1937) Microdetermination of chloride in biological fluids with solid silver iodate. 2. Titrimetric analyses. 7. biol. Chem. 120. 405.

Stern, I. \& Shapiro, B. (1953) A rapid and simple method for the determination of esterified fatty acids and for total fatty acids in blood. 7 . clin. Path. 6, 158.

VAN SLyKe, D. D. (1922) Studies of acidosis. 18. Determination of bicarbonate concentration of the blood and plasma. 7. biol. Chem. 52, 495.

White, I. G. (1959) Studies on the estimation of glycerol, fructose and lactic acid. Aust. F. exp. Biol. med. Sci. 37, 441.

White, I. G. \& WALEs, R. G. (1961) Comparison of epididymal and ejaculated semen of the ram. 7. Reprod. Fertil. 2, 225.

Yoffey, J. M. \& Courtice, F. C. (1956) Lymphatics, lymph and lymphoid tissue. Harvard University Press, Cambridge, Mass.

Zilversmit, D. B. \& DAvis, A. K. (1950) Microdetermination of plasma phospholipids by trichloracetic acid precipitation. F. Lab. clin. Med. 35, 155. 